\title{
GREEN INVESTMENT DAN CORPORATE GOVERNANCE TERHADAP NILAI PERUSAHAAN: PROFITABILITAS SEBAGAI PEMEDIASI
}

\author{
ADELLIA TANASYA \\ SUSI HANDAYANI \\ Jurusan Akuntansi, Fakultas Ekonomi Universitas Negeri Surabaya, Jl. Ketintang No.2 Ketintang, Kec. \\ Gayungan, Kota Surabaya, Indonesia \\ adelliatanasya16080694010@mhs.unesa.ac.id
}

\begin{abstract}
The purpose of this study determines the effect of corporate governance and green investment on firm value with profitability as a mediating variable. Corporate governance variables are proxied by independent commissioners, audit committees, managerial ownership, and managerial ownership. While the green investment variable is proxied by PROPER rating. This study uses 40 samples of companies registered in the 2014-2018 SRI KEHATI Index. The data analysis technique used is path analysis and multiple tests. The results of the study prove that corporate governance and green investment affect profitability, profitability influences peer value, and profitability can mediate the relationship between green investment and firm value.
\end{abstract}

Keywords: Green investment, corporate governance, profitability, firm value

\begin{abstract}
Abstrak: Penelitian ini bertujuan untuk mengetahui pengaruh hubungan corporate governance dan green investment terhadap nilai perusahaan dengan profitabilitas sebagai variabel mediasi. Variabel corporate governance diproksikan dengan komisaris independen, komite audit, kepemilikan manajerial, dan kepemilikan manajerial. Sedangkan variabel green investment diproksikan dengan peringkat PROPER. Penelitian ini menggunakan 40 sampelperusahaan yang terdaftar di Indeks SRI KEHATI 2014-2018. Teknik analisis data yang digunakan adalah analisis jalur dan uji sobel. Hasil penelitian meembuktikan bahwa corporate governance dan green investment berpengaruh terhadap profitabilitas, Profitabilitas berpengaruh terhadap nilai peerusahaan, dan profitabilitas dapat memediasi hubungan antara green investment tehadap nilai perusahaan.
\end{abstract}

Kata kunci: Green investment, corporate governance, profitabiltas, nilai perusahaan

\section{PENDAHULUAN}

Modal eksternal dalam sebuah perusahaan dapat digunakan untuk memenuhi kebutuhan pokok perusahaan seperti kegiatan oprasional dan investasi. Bukan hanya itu di era globalisasi saat ini menimbulkan adanya perkembangan perekonomian di dunia serta majunya ilmu pengetahuan dan teknologi, hal ini membuat perusahaan harus berusaha menciptakan nilai yang baik dengan begitu akan menarik investor untuk menanam modal saham di perusahaan. Selain perusahaan, investor juga akan mencari perusahaan dengan nilai yang baik sehingga investor akan mendapatkan keuntungan yang lebih. Nilai perusahan dapat diukur menggunakan harga pasar saham suatu perusahaan. Tingginya 
keinginan investor dalam memiliki saham pada sebuah perusahaan, membuat perusahaan tersebut mendapatkan citra dan nilai yang baik. Kondisi seperti ini tentu akan memengaruhi harga saham yang beredar. Ketika para investor banyak memburu saham perusahaan tertentu, maka harga saham tersebut akan mengalami kenaikan. Tingginya keinginan investor dalam mendapatkan saham perusahaan membuat modal saham yang ditanamkan juga tinggi, hal ini karena investor percaya dan mengganggap perusahaan dapat memberikan keuntungan (Indiani \& Dewi 2016).

Menurut Dwiridotjahjono (2010) praktik corporate governance mampu menambah nilai pada perusahaan. Implementasi corporate governance bisa meminimalisasi masalahmasalah keagenan yang ada dalam perusahaan, adanya pemisahan tugas dan kepentinggan antara manajer dengan para pemilik perusahaan menimbulkan masalah keagenan. Adanya corporate governance dapat menimbulkan kerja sama dengan baik dan menyatukan kepentingan dari kedua belah pihak sehingga tujuan dari perusahaan dapat dicapai sehingga mampu menambah nilai perusahaan. Hal tersebut didukung dengan adanya pembaruan UU No. 40 tahun 2007 yang mengatur mengenai Perseroan Terbatas. Pembaruan UU ini mengenai Perseroan Terbatas tersebut diharapkan perusahaan yang berada di Indonesia dapat mengimplementasikan corporate governance dengan baik (Undang-Undang Republik Indonesia Nomor 40 Tahun 2007, 2007). Perusahaan yang menjalankan strategi dengan corporate governance bisa meningkatkan nilai perusahaan, bukan hanya itu perusahaan juga harus memperhatikan lingkungan dan sosialnya.

Menurut Muchti (2014) kegiatan perusahaan menenai tanggung jawab lingkungan akan membuat perusahaan mendapat apresiasi dari para stakeholder. Salah satu tanggung jawab perusahaan terhadap lingkungan merupakan suatu keputusan investasi jangka panjang, dimana dengan peduli terhadap lingkungan dapat memperbaiki citra perusahaan yang mana akan berdampak pada nilai perusahan dalam jangka panjang. Green investment sebagai upaya perusahaan dalam mengelola masalah lingkungan dengan mengurangi dampak negatif dari kegiatan bisnis terhadap lingkungan oleh karena itu green investment dapat meningkatkan keunggulan kompetitif, reputasi, dan nilai perusahaan. Penerapan green investment merupakan salah satu strategi perusahaan dalam meningkatkan keuntungan tanpa merusak lingkungan hidup.

Investor menginginkan perusahaan menerapkan corporate governance dan green investment dengan baik seiring dengan perkembangan ekonomi dan banyaknya persaingan. Hal tersebut membuat menajemen dituntut untuk lebih baik dalam menjalankan tugasnya sehingga akan mempengaruhi profitabilitas yang kemudian meningkatkan nilai pada perusahaan. Profitabilitas yaitu upaya yang dilakukan oleh perusahaan guna memperoleh profit selama satu periode akuntansi (Sanjaya \& Rizky, 2016). Profitabilitas mampu menjadi perantara dalam upaya meningkatkan nilai perusahaan. Tinggi rendahnya profitabilitas pada perusahaan akan mempengaruhi harga saham suatu perusahaan. Profitabilitas digunakan oleh investor untuk mencari informasi yang dibutuhkan. Tingginya profitabilitas perusahaan membuat para investor mempunyai keyakinan bahwa perusahaan mampu bertahan dalam persaingan, hal ini akan memberikan respon positif investor terhadap perusahaan dengan memiliki saham perusahaan tersebut. Perusahaan-perusahaan yang melakukan kegiatan green investment dan corporate governance dapat mempengaruhi profitabilitas kemudian mampu mencapai tujuan dari perusahaan, yaitu memaksimalkan nilai pemegang saham. 
Investor akan memilih perusahaan untuk menginvestasikan modalnya dengan melihat kinerja saham melalui indeks, salah satunya indeks SRI-KEHATI, Indeks SRIKEHATI yaitu suatu indeks yang menjadi indikator pergerakan harga saham yang memiliki kinerja keberlanjutan dengan menerapkan corporate governance serta memiliki kepedulian tentang lingkungan hidup (Dewi 2014).

Berdasarkan latar belakang diatas penelitian ingin mengetahui pengaruh corporate governance dan green investment terhadap nilai perusahaan yang dimediasi oleh profitabilitas. Hasil dari pengujian diharapkan bisa membantu pihak-pihak dari perusahaan guna meningkatkan nilai perusahaan terkait penerapan corporate governance dan green investment dengan profitabilitas sebagai mediator.

\section{Teori Keagenan}

Menurut Jensen \& Meckling (1976), adanya teori agensi berasal dari perbedaan kepentingan principle dengan pihak manajemen. Konflik agensi dapat dikurangi dengan cara implementasi corporate governance pada perusahaan. Dengan diterapkannya corporate governance pada perusahaan mampu meyakinkan para pemangku kepentingan (stakeholder) bahwa manajemen melakukan tugasnya selaras dengan tujuan perusahaan, sehingga masalah antara pihak manajer dengan pemilik perusahaan dapat diminimalisasi.

\section{Teori Legitimasi}

Teori legitimasi pertama kali diperkenalkan oleh Dowling \& Pfeffer (1975). Legimitasi merupakan suatu kecenderungan dalam keberpihakan perseorangan maupun suatu kelompok yang peduli terhadap kondisi lingkungan. Legitimasi memiliki hubungan dengan usaha perusahaan dalam melakukan kegiatan bisnis dan operasional yang sesuai dengan norma lingkungan masyarakat. Usaha yang dilakukan perusahaan dilaksanakan karena legitimasi masyarakat merupakan salah satu aspek penentu kelangsungan proses bisnis perusahaan.

\section{Signaling theory}

Signaling theory dicetuskan oleh Spence (1973), Signaling theory merupakan cara investor memandang kenaikan nilai perusahaan, informasi ini diberikan oleh manajemen kepada pemegang saham atau pengguna laporan keuanngan. Perusahaan memiliki insentif pelaporan informasi ke pasar modal, hal ini dilakukan oleh manajemen guna mendapatkan dan mempertahankan investor perusahaan. Informasi mengenai keuangan dapat meminimalkan asimetri informasi dari manajer dan pihak eksternal. Publikasi yang dilakukan oleh perusahaan bisa digunakan sebagai signal oleh investor untuk mengambil keputusan investasi.

\section{Green Investment}

Menurut Rachman (2018) green investment adalah suatu aktivitas penanaman modal pada perusahaan yang berinvestasi dengan miliki komitmen pada fokus sumber daya alam (SDA), produksi, serta penciptaan sumber alternatif energi baru dan keterbaruan (EBIT), pengimplementasian proyek air dan udara bersih, serta kegiatan investasi lain yang ramah lingkungan. IMF menilai bahwa green investment merupakan investasi yang dibutuhkan guna meminimalkan emisi gas rumah kaca dan polusi udara tanpa mengurangi proses bisnis perusahaan nonenergi baik investasi publik maupun swasta (Eyraud \& Wane, 2011).

\section{Corporate Covernance}

Corporate governance merupakan sistem pengendalian perusahaan yang mempunyai fungsi yaitu pengelolaan risiko perusahaan untuk mencapai tujuan bisnisnya dengan cara mengamankan aset perusahaan serta menambah nilai investasi investor jangka panjang (Effendi, 2016). Implementasi 
corporate governance memberikan manfaat yang besar bagi perusahaan salah satunya manfaat mendapatkan respon yang baik dari para investor maupun pasar. Perusahaan dapat mengatasi masalah yang terjadi dengan cara mengimplementasikan prinsip corporate governance diantaranya prinsip transparansi, prinsip akuntabilitas, prinsip responsibility, prinsip independen, dan prinsip fairness. Menurut Fathonah (2016) prinsip corporate governance bisa diwakili dengan adanya komisaris independen, komite audit, kepemilikan manajerial, dan kepeilikan.

\section{Profitabilitas}

Suatu upaya yang dilakukan oleh perusahaan guna menghasilkan keuntungan selama satu periode akuntansi merupakan profitabilitas (Sanjaya \& Rizky, 2016). Investor menggunakan profitabilitas sebagai bahan pertimbangan dalam investasinya, karena besarnya deviden membuat perusahaan mampu bersaing selain itu kinerja manajer menjadi lebih meningkat dan bisa meningkatkan kepemilikan karena banyaknya deviden yang diperoleh. Tingginya imbal hasil diharapkan mampu menarik investor guna berinvestasi pada perusahaan. Profitabilitas dapat digunakan sebagai dasar penilaian kondisi perusahaan, dengan begitu guna mengetahui kondisi perusahaan dapat menggunakan rasio profitabitas. Rasio profitabilitas bisa menggambarkan kinerja manajemen dalam melaksanakan tugasnya dengan melihat besarnya laba yang diperoleh perusahaan.

\section{Nilai Perusahaan}

Suatu nilai yang harus dipertahankan dan dijaga oleh setiap perusahaan adalah nilai perusahaan. Nilai perusahaan mencerminkan keadaan tentang pecapaian kinerja perusahaan berdasarkan hasil seberapa besar masyarakat percaya kepada perusahaan. Pengukuran nilai perusahaan dilakukan dengan menilai harga saham yang berada di pasar. Harga saham dapat memperlihatkan seberapa besar nilai perusahaan melalui penilaian publik terhadap kinerja perusahaan (Syafitri dkk., 2018). Ketika perusahaan mampu menaikkan nilai perusahaan menjadi tinggi maka perusahaan akan memperoleh keuntungan yang maksimal.

\section{Pengaruh Corporate Governance tehadap Profitabilitas.}

Implementasi corporate governance dapat dilakukan sesuai prinsipnya, prinsip corporate governance dapat diwakili antara lain dengan komisaris independen, komite audit, kepemilikan manajerial, kepemilikan institusional. Pengaruh komisaris independen terhadap profitabilitas. Berkenaan dengan teori keagenan adanya pengendalian internal seperti komisaris independen bisa mengurangi biaya agensi, hal ini dikarenakan pengawasan yang dilakukan secara independen terhadap manajemen mampu meningkatkan pengendalian. Tingginya pengawasan komisaris independen terhadap pihak manajemen membuat manajemen melakukan tugasnya sesuai dengan tujuan perusahaan sehingga profitabilitas perusahaan akan meningkat.

Pengaruh komite audit pada profitabilitas, Komite audit bisa membantu mengurangi masalah keagenan karena komite audit memiliki tugas menilai pengendalian internal, mengawasi proses pembuatan laporan keuangan, serta meningkatkan fungsi audit menjadi lebih efektif (Prasetyo, 2014). Pengawasan secara optimal dilakukan komite audit ketika proses menyusun laporan keuangan, hal ini dimaksudkan untuk memperoleh kualitas laporan keuangan yang terhindar dari kecurangan dari pihak manjer, sehingga mampu meningkatkan profitabilitas perusahaan.

Pengaruh kepemilikan manajerial terhadap profitabilitas. adanya kepemilikan manajerial pada perusahaan dapat dapat meningkatkan keuntungan karena adanya rasa memiliki dari pihak manajemen terhadap 
perusaahaan. Hal ini berkenaan dengan teori agensi yang mana bisa menyatukan kepentingan manajer dengan principle untuk mencapai tujuan perusahaan. apabila manajemen memiliki jumlah presentase saham yang tinggi, maka maka kinerja manajemen semakin meningkat yang kemudian akan menghasilkan profitabilitas yang tinggi. Menurut Agustina \& Jogi (2015) kepemilikan manajerial dapat meningkatkan profitabilitas perusahaan.

Pengaruh kepemilikan institusionalpada profitabilitas. Berdasarkan teori agensi adanya monitoring dari pihak institusi terhadap kinerja manajemen dapat mengurangi biaya keagenan. Besarnya jumlah saham yang ditanamkan pihak institusi pada perusahaan membuat monitoring terhadap pihak manajemen menadi efektif. Hal ini dilakukan karena priciple ingin memastikan bahwa modal yang diinvestasikan dimanfaatkan untuk kepentingan operasional perusaahaan sehingga memperoleh profitabilitas yang tinggi. Apabila presentase saham yang dimiliki oleh pihak institusi banyak, maka semakin efektif pemanfaatan aktifa oleh perusahaan. Dengan demikian adanya kepemilikan institusional bisa mengurangi inefisiensi dari pihak manajemen sehingga dapat meningkatkan profitabilitas perusahaan. Dengan demikian hipotesis pertama yang dirumuskan sebagai berikut:

$\mathrm{H}_{1}$ : Corporate governance berpengaruh terhadap Profitabilitas.

\section{Pengaruh Green Investment terhadap Profitabilitas}

Penerapan green investment merupakan salah satu stategi perusahaan guna meningkatkan keuntungan tanpa merusak lingkungan hidup. Green investment dapat memberikan legitimasi masyarakat terhadap perusaahaan, hal ini karena perusahaan berupaya untuk beroriantasi sesuai norma yang berlaku pada masyarakat dan lingkngan. Apabila perusahaan telah mendapatkan legitimasi masyarakat maka kegiatan bisnis dari perusahan akan didukung oleh masyarakat sehingga profitabilitas perusahaan akan mengalami peningkatan. Dengan demikian hipotesis kedua sebagai berikut:

$\mathrm{H}_{2}$ : Green Investment berpengaruh terhadap Profitabilitas.

\section{Pengaruh Profitabilitas terhadap Nilai Perusahaan}

Tingginya profitabilitas yang dimiliki oleh suatu perusahaan dapat mengindikasikan bahwa prospek perusahaan di masa mendatang juga lebih baik. Informasi mengenai profitabilitas akan dapat dilihat pada laporan keuangan yang diterbitkan oleh perusahaan sebagai informasi untuk investor dan para pengguna laporan keuangan. Sinyal positif dari informasi laporan keuangan dimaksudkan untuk menarik investor guna menanamkan modal sahamnya kepada perusahaan. Ketika laba perusahaan mengalami peningkatan maka harga saham perusahaan juga mengalami peningkatan. Tingginya harga saham menggambarkan perusahaan memiliki nilai yang baik. Hal ini didukung dengan penelitian Sumarau (2019) yang menyatakan tingginya profitabilitas mampu meningkatkan nilai perusahaan, sehingga hipotesis ketiga dapat dirumuskan sebagai berikut:

$\mathrm{H}_{3}$ : Profitabilitas berpengaruh terhadap nilai perusahaan.

\section{Pengaruh corporate governance terhadap Nilai Perusahaan melalui profitabilitas}

Konflik keagenan dapat diminimalkan dengan adanya peran dari kepemilikan institusional. Adanya pihak institusi dapat memonitoring secara optimal kinerja dari manajemen sehingga perusahaan mampu memberikan profit yang besar. Tingginya profitabilitas pada suatu perusahaan akan berpengaruh terhadap citra dan nilai perusahaan tersebut. Perusahaan yang memiliki nilai yang baik akan menarik investor guna menanamkan saham pada perusahan.

Kepemilikan manajerial mampu mengurangi masalah keagenan yang terjadi 
pada perusahaan. Adanya saham manajer pada perusahaan mabuat manajer harus mempertimbangkan keputusan yang diambilnya karena akan berpengaruh terhadap saham yang ditanamnya pada perusahaan. Besarnya kepemilikan manajerial meningkatkan kinerja dari manajemen yang dapat mempengaruhi pertumbuhan profitabilitas. Profitabilitas yang baik akan menambah nilai dari perusahaan, yang mana dapat membuat investor percaya pada perusahaan akan memberikan deviden yang besar.

Komisaris independen sangat efektif dalam melakukan pengawasan pada kinerja manajer sehingga dapat meminimalkan konflik keagenan. Dengan adanya pengendalian tersebut manajer akan bekerja secara profesional sehingga profitabilitas dapat ditingkatkan. Apabila pertumbuhan profitabilitas sangat baik, maka akan meeningkatkan nilai dari perusahaan.

Komite audit memiliki tugas yaitu memelihara kredibilitas penyusunan laporan keuangan Apabila tugas komite audit dapat dilakukan secara efektif maka pengendalian pada perusahaan akan lebih baik, dengan demikian masalah agensi dapat diminimalkan sehingga profitabilitas perusahaan dapat ditingkatkan. Adanya peninangkatan profitabilitas akan menambah nilai dan citra dari perusahaan. dengan demikian hipotesis keempat sebagai beriku: $\mathrm{H}_{4}$ : corporate governance berpengaruh terhadap nilai perusahaan melalui profitabilitas.

Pengaruh Green Investment terhadap Nilai Perusahaan melalui Profitabilitas

Implementasi dari green investment dapat memberikan legitimasi masyarakat terhadap perusahaan. Adanya dukungan masyarakat terhadap perusahaan maka produktifitas dan profitabilitas perusahaan mengalami kenaikan. Naiknya pertumbuhan profitabilitas yang dapat dilihat pada laporan keuangan akan berpengaruh terhadap permintaan saham dan harga saham perusahaan. Harga Saham yang tinggi mencerminkan nilai perusahaan yang baik. Dengan demikian profitabilitas memediasi hubungan green investment terhadap nilai perusahaan, dengan demikian hipotesis yang diajukan adalah:

$\mathrm{H}_{5}$ : Green Investment berpengaruh terhadap Nilai Perusahaan melalui Profitabilitas.

\section{METODA}

Jenis penelitian menggunakan penelitian kualitatif dan data sekunder berupa laporan keuangan perusahaan yang terdaftar di bursa efek indonesia (www.idx.co.id). Sampel yang digunakan yaitu perusahaan indeks SRI KEHATI tahun 2014-2018. Pemilihan sampel menggunakan metode purposive sampling, berikut karakteristik yang digunakan:

Tabel 1 Karakteristik Pemeilihan Sampel

\begin{tabular}{clc}
\hline No. & \multicolumn{1}{c}{ Keterangan } & Jumlah Perusahaan \\
\hline 1. & Perusahaan Indeks SRI KEHATI yang terdaftar di BEI dalam & 125 \\
& periode 2014-2018 & -70 \\
2. & Perusahaan yang memperoleh penghargaan PROPER & -15 \\
3 & Perusahaan yang tidak memiliki kelengkapan data & 40 \\
\hline Total perusahaan yang digunakan sebagai sampel &
\end{tabular}


Nilai perusahaan dapat dihitung menggunakan perhitungan Tobins'Q. Pengukuran menggunakan perhitungan Tobin's $Q$ bisa memberi gambaran menganai nilai pasar suatu perusahaan yang lebih komprehensif perhitungannya sebagai berikut:

Keterangan:

$$
\text { Tobin's } Q=\frac{(M V+B V L)}{B V A}
$$

\section{MV : Market Value \\ BVL : Book Value of Liabilities \\ BVA : Book Value of Asset}

Variabel corporate governance menggunakan proksi yang sesuai dengan prinsipnya yang dapat diwakili dengan komisaris independen dalam suatu perusahaan merupakan bagian dari dewan komisaris tetapi tidak mempunyai hubungan dari pihak manajer dengan pihak lain yang berpengaruh terhadap kepentingan perusahaan, sehingga dapat bertindak secara independen. Perusahaan mempunyai komisaris independen paling tidak 30\% dari dewan komisaris sesuai dengan pedoman good corporate governance untuk mempertahankan independensi serta dalam mengambil keputusan dengan tepat, rumus untuk menghitungnya berikut:

$$
=\frac{\text { Jumlah Komisaris Independen }}{\text { Jumlah Anggota dewan komisaris }}
$$

Komite audit bertugas untuk membantu dan mendorong kinerja dari dewan komisaris dalam mengawasi tahap-tahap pelaporan keuangan, memanajemen risiko, prosses auditing, serta pengimplementasian corporate governance. Rumus komite audit yaitu jumlah dari anggota komite audit.

Kepemilikan manajerial pada suatu perusahaan merupakan presentase saham dari manajemen perusahaan. Besarnya presentase saham manajerial pada perusahaan mampu menyelaraskan kepentingan dengan para pemegang saham. Rumus perhitungan kepemilikan manajerial sebagai berikut:

$$
=\frac{\text { Jumlah saham yang dimiliki manajemen }}{\text { Jumlah saham yang beredar }}
$$

Adanya kepemilikan institusional bisa memonitoring kinerja perusahaan karena banyaknya saham yang ditanamkan pada perusahaan, hal ini membuat pengendalian terhadap manajemen tinggi yang keudian akan meminimalikan tingkat kecurangan. Kepemilikan institusional bisa dihitung menggunakna rumus sebagai berikut:

$$
=\frac{\text { Jumlah saham institusional }}{\text { Jumlah saham yang beredar }}
$$

Pengukuran Green investment sebagai upaya perusahaan dalam mengelola masalah lingkungan dengan mengurangi dampak negatif dari kegiatan bisnis terhadap lingkungan oleh karena itu green investment dapat meningkatkan keunggulan kompetitif, reputasi dan nilai perusahaan. Pengukuran green investment dapat menggunakan peringkat PROPER Ada 5 tingkatan dalam peringkat PROPER yaitu peringkat pertama diberi warna emas, peringkat kedua diberi warna hijau, peringkat ketiga diberi warna biru, peringkat keempat diberi warna merah, dan peringkat terahir diberi warna hitam (Kementrian Lingkungan Hidup, 2013). Pemberian peringkat berdasarkan kategori ini sudah ditetapkan dan di publikasikan karena membantu memudahkan pemaham investor dan masyarakaat mengenai penilaian kriteria PROPER perusahaan.

Profitabilitas dapat dihitung dengan ROE. ROE digunakan untuk menghitung keuntungan yang dihasilkan dari modal perusahaan. ROE dapat dihitung dengan cara memperbandingkan keuntungan bersih dengan total modal perusahaan Putra and Nuzula (2017)

$$
R O E=\frac{\text { Laba Bersih }}{\text { Ekuitas }}
$$

Teknik analisis yang digunakan dalam penelitian ini adalah analisis jalur (path 
analysis) dan uji sobel. Terdapat dua model persamaan untuk analisis jalur adalah:

$$
\begin{aligned}
Z= & \propto+b_{1} X 1+b_{2} X 2+b_{3} X 3+b_{4} X 4+ \\
& b_{5} X 5+\varepsilon \ldots \ldots(1) \\
Y= & \propto+b_{1} X 1+b_{2} X 2+b_{3} X 3+b_{4} X 4+ \\
& b_{5} X 5+Z+\varepsilon \ldots(2)
\end{aligned}
$$

Data penelitian dianalisis dengan descriptive statistics, kemudian melakukan uji asumsi klasik dan uji hipotesis. Untuk mengelola data menggunakan SPSS versi 25 .

\section{HASIL DAN PEMBAHASAN}

Statistik deskriptif data dilakukan sebelum uji asumsiklasik. Analisis deskriptif statistik berikisan dari data penelitian diantaranya mecangkup banyaknya sampel, nilai terendah dan tertinggi, rata-rata nilai, serta standar deviasi. Berikut ini hasil pengujian:

Tabel 2 Hasil Uji Descriptive Statistics

\begin{tabular}{lrrrrr}
\hline Variabel & N & Min & Max & Mean & Std. Deviation \\
\hline Komisaris Independen & 40 & 28,57 & 50,00 & 37,9573 & 6,38082 \\
Komite audit & 40 & 3 & 5 & 3,45 &, 597 \\
Kepemilikan Manajerial & 40 &, 00000 & 1,52971 &, 1043648 &, 36172065 \\
Kepemilikan institusional & 40 & 38,93 & 99,02 & 81,2943 & 19,72224 \\
PROPER & 40 & 3 & 5 & 3,50 &, 599 \\
ROE & 40 & 2,00 & 23,30 & 11,4428 & 5,49140 \\
Tobins'Q & 40 & 8,27 & 22,49 & 13,3253 & 3,25212 \\
Valid N (listwise) & 40 & & & & \\
\hline
\end{tabular}

\section{Sumber: Data diolah,2020}

Dari tabel 2 diketahui bahwa jumlah sampel sebanyak 40 dan nilai komisaris independen terendah adalah 28,57 , untuk nilai tertinggi yaitu 50,00 , kemudian untuk rata-rata adalah 38,95 . Komite audit memiliki nilai terendah yaitu 3 dan nilai tertinggi 5 serta mean senilai 3,45. Kepemilikan manajerial memiliki nilai terendah sebesar 0,00 sedangkan nilai teringginya 1,52 , dan mean sebesar 0,1043648. Nilai kepemilikan institusional terendah adalah 38,93 , untuk nilai tertinggi yaitu 99,02 , kemudian untuk rata-rata adalah 81,29 . PROPER memiliki nilai terendah yaitu 3 dan tertnggi 5 , untuk ratarata senilai 3,50. Nilai variabel mediasi $R O E$ terendah adalah 2,00 untuk nilai tertinggi yaitu 23,30 , kemudian untuk rata-rata adalah 11,44 yang menunjukan bahwa profitabilitas dalam menghasilkan laba dengan menggunakan modal sebesar $11,44 \%$. Nilai perusahaan memiliki nilai terendah 8,27 dan 22,49 untuk tertingginya, serta mean sebesar 13,32 dimana investor menganggap bahwa keberhasilan perusahaan bisa dilihat dari nilai perusahaan.

Tabel 3 Uji Hipotesis t persamaan 1

\begin{tabular}{lrrr}
\hline \multicolumn{1}{c}{ Model } & \multicolumn{3}{c}{ Std. } \\
\hline B & \multicolumn{1}{c}{ Error } & Sig. \\
\hline Komisaris Independen & 8,838 & 10,063 &, 386 \\
Komite Audit &,- 263 &, 137 &, 064 \\
Kepemilikan Manajerial &, 005 & 1,418 &, 997 \\
Kepemilikan Institusional &,- 355 & 2,396 &, 032 \\
PROPER & 3,780 & 1,346 &, 008 \\
\hline Sumber: Data diolah 2020 & & &
\end{tabular}

Sumber: Data diolah,2020 
Berdasarkan tabel 3 diketahui bahwa variabel corporate governance yang memiliki pengaruh signifikan terhadap profitabilitas adalah kepemilikan manajerial karena nilai signifikan 0,032 lebih kecil dari 0,05 sedangkan komisaris independen memberikan hasil yang tidak memiliki pengaruh karena signifikan 0,064 , komite audit tidak berpengaruh karena memiliki nilai 0,997, dan kepemilikan institusional juga tidak berpengaruh karena signifikansinya 0,730 . Untuk variabel green investment berpengaruh signifikan pada profitabilitas karena nilai signifikasinya sebesar 0,008 yang lebih kecil dari 0,05 .

Tabel 4 Uji Hipotesis t persamaan 2

Std.

Model B Error Sig.

\section{Uji Analisis jalur}

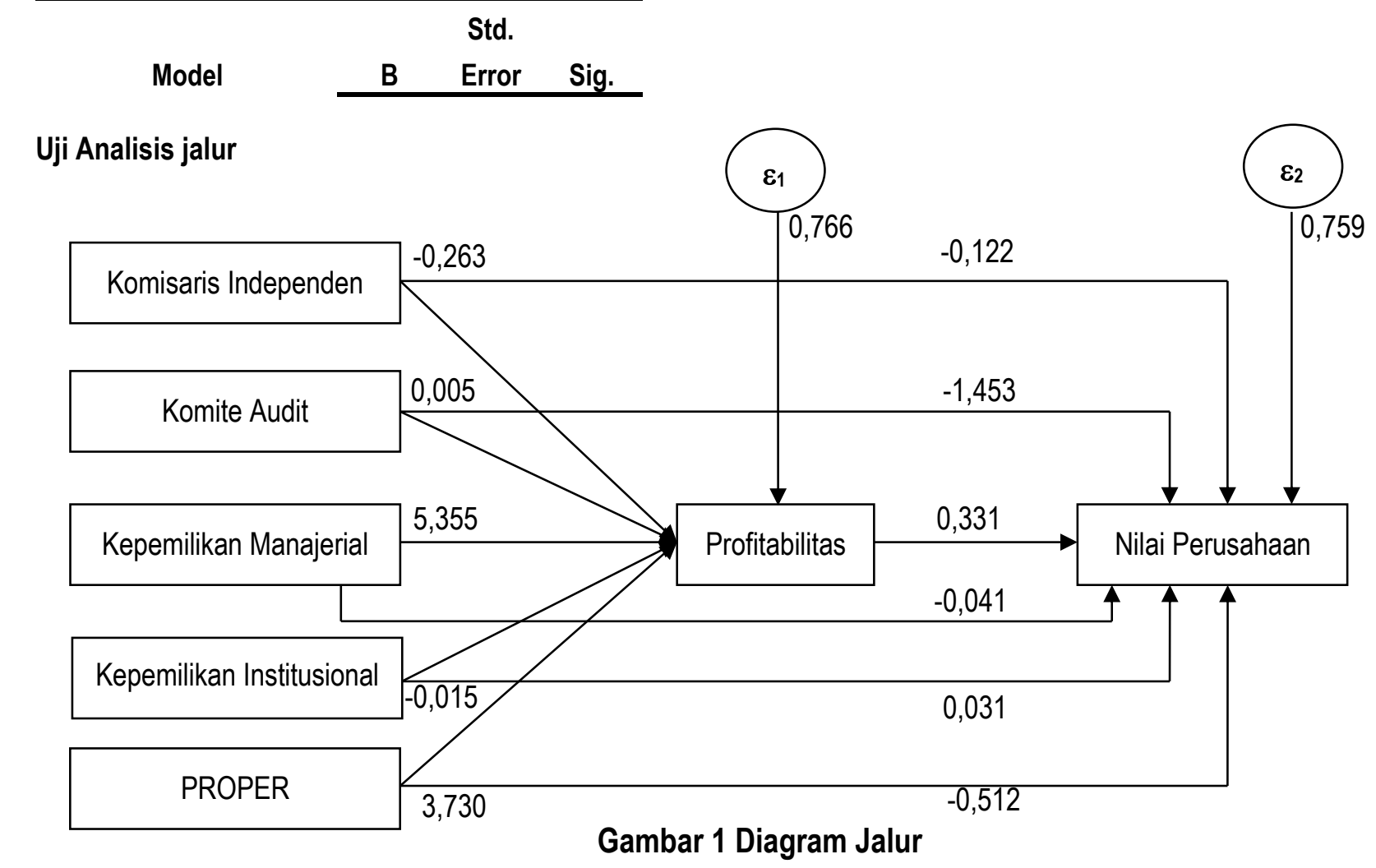

Berdasarkan analisis jalur nilai koefisien diperoleh dari nilai unztandardized beta. Nilai koefisien $\varepsilon 1=\sqrt{1-0,412}=0,766$

\begin{tabular}{lrrr}
\hline (Constant) & 18,418 & 6,058 &, 005 \\
Komisaris Independen &,- 122 &, 086 &, 167 \\
Komite Audit & $-1,453$ &, 844 &, 094 \\
Kepemilikan Manajerial &,- 041 & 1,528 &, 979 \\
Kepemilikan Institusional &, 031 &, 026 &, 236 \\
PROPER &,- 512 &, 889 &, 569 \\
ROE &, 331 &, 102 &, 003 \\
\hline Sumber: Data diolah,2020 & &
\end{tabular}

Dari tabel 4 dapat dilihat variabel corporate governance tidak memiliki pengaruh pada nilai perusahaan karena semua proksinya memiliki nilai signifikan yang lebih dari 0,05. Variabel green investment tidak mempengaruhi nilai perusahaan karena signifikansinya 0,569 lebih besar dari 0,05 Sedangkan variabel profitabilitas memiliki signifikan terhadap nilai perusahaan karena nilai signifikansinya 0,003 lebih kecil dari 0,05. 
pada variabel nilai perusahaan, sehingga dapat disimpulkan corporate governance tidak memberikan pengaruh secara langsung pada nilai perusahaan sama seperti variabel independen yang satunya yaitu green investment tidak memiliki pengaruh terhadap variabel nilai perusahaan. Dengan demikian dapat disimpulkan green investment tidak memeberikan pengaruh secara langsung pada nilai perusahaan. Sedangkan profitabilitas sebagai variabel mediasi berpengruh pada nilai perusahaan. Persamaan dari diagram jalur sebagai berikut:

$$
\begin{gathered}
Z=0,263 X 1+0,005 \times 2+5,355 \times 3 \\
-0,015 X 4+3,730 \times 5+0,766
\end{gathered}
$$

Berdasarkan persamaan 1 dapat disimpulkan semua variabel independen meningkatkan profitabilitas sebesar 23,4\% sedangkan sisanya 0,766 atau $76,6 \%$ dipengaruhi faktor lainya.

$$
\begin{gathered}
Y=-0,122 \mathrm{X} 1-1,453 \mathrm{X} 2-0,041 \mathrm{X}+ \\
0,031 \mathrm{X} 4-0,512 \mathrm{X} 5+0,333 \mathrm{Z}+0,759 \\
\text { Berdasarkan persamaan } 2 \text { disimpulkan }
\end{gathered}
$$
semua variabel independen dan variabel mediasi meningkatkan nilai perusahaan sebesar $24,1 \%$ sedangkan sisanya 0,759 atau $75,9 \%$ dipengaruhi faktor lainya.

Tabel 5. Hasil Uji Sobel

\begin{tabular}{|l|c|c|}
\hline & \multicolumn{1}{|c|}{ Sp2p3 } & $t_{\text {hitung }}$ \\
\hline Kepemilikan Manajerial & 0,9870 & 1,7998 \\
\hline Komisaris Independen & 0,0545 & 1,5973 \\
\hline Komite Audit & 0,4113 & 0,0034 \\
\hline Kepemilikan Institusional & 0,0149 & 0,0333 \\
\hline Proper & 0,5987 & 2,0906 \\
\hline
\end{tabular}

Sumber: Data diolah, 2020

Berdasarkan hasil uji sobel nilai tabel dengan signifikan 0,05 sebesar 2,0301. Nilai $t_{\text {hitung }}$ pada koefisien jalur pengaruh tidak langsung semua proksi variabel corporate governance kurang dari nilai $t_{\text {tabel }}$ sehingga menunjukan profitabilitas sebagai mediasi tidak mampu menghubungkan antara corporate governance dengan nilai perusahaan. Sedangkan nilai thitung pada koefisien jalur pengaruh tidak langsung variabel green investment sebesar 2,0906 sedangkan nilai $t_{\text {tabel }}$ dengan signifikan 0,05 sebesar 2,0301 dimana thitung lebih dari $t_{\text {tabel. }}$ Hasil ini membuktikan bahwa profitabilitas dapat menjadi mediator hubungan green investment dengan nilai perusahaan.

Dari tabel 3 dapat disimpulkan $\mathrm{H} 1$ diterima artinya corporate governance yang diwakili oleh kepemilikan manajerial berpengaruh pada profitabilitas. Kepemilikan manajerial memiliki pengaruh terhadap profitabilitas, hal ini sesuai dengan teori keagenan, dengan adanya saham pihak manajemen di perusahaan dapat menyatukan kepentingan pihak manajer dengan pemilik perusahaan. Kepemilikan manajerial mampu mendorong motivasi dari manajemen guna meningkatkan kinerjanya untuk mencapai tujuan perusahaan. Apabila kinerja perusahaan meningkat maka profitabilitas perusahaan juga akan naik. Ketika profitabilitas naik maka manajer juga akan memperoleh keuntungan karena manajer memiliki kepemilikan pada perusahaan, dengan begitu kepemilikan manajerial membuat profitabilitas mengalami peningkatan. Penelitian ini didukung oleh Agustina \& Jogi (2015) dan penelitian Murwaningsari (2009).

Banyaknya komisaris independen dalam perusahaan belum sepenuhnya efektif dalam menjalankan tugasnya, hal ini berarti peningkatan kinerja suatu perusahaan yang dilakukan oleh komisaris independen masih kurang efektif. Perusahaan hanya mematuhi peraturan mengenai adanya komisaris independen perusahaan tanpa mempertimbangkan kemampuan komisaris independen tersebut sehingga fungsi monitoring tidak berjalan dengan optimal. Berkenaan dengan teori keagenan yang menyatakan banyaknya anggota komisaris independen yang kurang kompeten menyulitkan monitoring terhadap manajemen. 
Dengan demikian ketika perusahaan memiliki komisaris independen yang kurang kompeten maka tugas monitoring yang dijalankan kurang efektif sehingga dalam mengawasi kinerja keuangan untuk menghasilkan profitabilitas tidak berpengaruh. Menurut Andriana \& Panggabean (2017) menyatakan bahwa komisaris independen sulit mempertahankan independensinya dalam perusahaan. Hasil ini selaras dengan penelitian Saputra dkk. (2017).

Banyaknya anggota komite audit tidak memiliki pengaruh pada profitabilitas suatu perusahaan, hal tersebut disebabkan monitoring yang dilakukan komisaris independen tidak mampu membuat manajemen menjalankan kebijakan dan stategi perusahaan dengan baik. Apabilia kinerja manajemen kurang efektif maka kinerja perusahaan tidak dapat ditingkatkan sehingga tidak akan mempengaruhi profitabilitas perusahaan. Bukan hanya itu tugas komite audit dalam memonitoring laporan penyusunan laporan keuangan dan membantu tugas komisaris independen belum maksimal sehingga profitabilitas belum mampu untuk ditingkatkan. Berdasarkan teori keagenan menjelaskan salah satu tugas komite audit yaitu membantu dewan komisaris, oleh sebab itu komite audit memiliki rangkap jabatan yang mempengaruhi penurunan kinerjanya. Hasil ini didukung oleh penelitian Rimardhani (2016) menurutnya komite audit tidak mempengaruhi profitabilitas karena dalam memilih anggota komite audit masih berdasarkan kekerabatan sehingga monitoring yang dijalankan komite audit kurang maksimal.

Kepemilikan institusional tidak memberikan pengaruh pada profitabilitas karena pada perusahaan yang menjadi sampel jumlah presentase saham yang ditanamkan pihak institusional tidak mampu mengendalikan sikap menejemen untuk bekerja sesuai aturan dan tujuan suatu perusahaan. Bukan hanya itu pihak institusional lebih memikirkan keuntunggan jangka pendek dan akan menarik kembali dana yang diinvestasikanya apabila perusahaan dirasa kurang menguntungkang, hal tersebut sesuai dengan teori keagenan hal ini sejalan dengan teori keagenan yang dilandasi dengan asumsi sifat manusia yaitu mementingkan pihak institusi sendiri. Hasil ini didukung oleh penelitian Andriana \& Panggabean (2017).

Dari tabel $3 \mathrm{H} 2$ diterima yang artinya variabel green investment berpengaruh signifikan pada profitabilitas. Penerapan green investment dalam perusahaan bisa memaksimalkan perolehan profitabilitas karena green investment dapat menimbulkan legitimasi masyarakat terhadap perusahaan. Hal ini karena perusahaan mempunyai hubungan dengan masyarakat dalam melakukan kegiatan yang mengandung nilai justice sehingga kegiatan investasi hijau perusahaan dapat diterima masyarakat. Berkenaan dengan teori legitimasi adanya dukungan dari masyarakat mengenai kegiatan lingkungan perusahaan yang sesuai norma yang berlaku pada masyarakat, maka kinerja perusahaan dapat berjalan dengan baik sehingga pertumbuhan profitabilitas mengalami peningkatan. Hal ini didukung dengan penelitian Yatie \& Tandika (2019) yang menyatakan implementasi dari green investment bertujuan untuk mengomunikasikan perusahaan dengan para stakeholder, yang kemudian memperoleh legitimasi dari masyarakat sehingga mempengaruhi profitabilitas perusahaan.

Tabel 3 menunjukan $\mathrm{H} 3$ diterima artinya profitabilitas berpengaruh pada variabel nilai perusahaan. Tingginya profitabilitas perusahaan yang diinformasikan melalui laporan keuangan membuat investor membeli saham perusahaan tersebut. Apabila saham perusahaan banyak dibeli oleh investor maka harga saham menjadi tinggi, dengan begitu nilai perusahaan menjadi lebih tinggi pula. Hal ini sejalan dengan teori sinyal yang mana profit tinggi memberikan sinyal positif bagi pengguna laporan keuangan bahwa perusahaan mempunyai kinerja yang baik dan mampu 
bersaing diantara perusahaan-perusahaan lain. Oleh karena itu, investor akan memperoleh manfaat dan keuntunggan di perusahaan tersebut. Hal tersebut menunjukan bahwa profitabilitas sangat penting untuk memberikan nilai suatu perusahaan. Selain itu tingginya profitabilitas menunjukan perusahaan dapat menjamin kemakmuran bagi pemegang saham dengan begitu akan menciptakan nilai pada perusahaan. Penelitian ini selaras dengan Sumarau (2019).

Hasil uji sobel menunjukan $\mathrm{H} 4$ ditolak artinya profitabilitas tidak mampu memediasi corporate governance pada nilai perusahaan, yang artinya investor dalam membeli saham tidak hanya berfokus kepada profitabilitas perusahaan, tetapi pada faktor lain yang bisa mempengaruhi nilai perusahaan. penelitian ini didukung oleh Oktaryani dkk. (2017).

Profitabilitas tidak mampu memediasi kepemilikan manajerial pada nilai perusahaan yang dapat diartikan apabila perusahaan medapatkan profit tinggi belum tentu membuat manajer guna meningkatkan nilai perusahaan. Hal ini sesuai dengan teori keagenan yang dilandasi asumsi sifat manusia. Pihak manajer mungkin berpendapat laba yang dihasilkan oleh perusahan hanya dinikmati oleh pemegang saham selain pihak manajemen, yang kemudian pihak manajer merasa tidak dapat menikmati profit yang dihasilkan oleh perusahaan. bukan dari manajemen secara lebih besar. Selain itu sampel penelitian ini menggunakan perusahaan yang memiliki tingkat kepemilikan manajerial yang rata-rata rendah yaitu hanya $1,04 \%$, sehingga nilai perusahaan tidak mengalami pengaruh meskipun sudah dimediasi dengan profitabilitas. phasil ini didukung oleh penelitian dari Fauziyyah (2019).

Profitabilitas tidak mampu memediasi hubungan komisaris independen terhadap nilai perusahaan. Tingginya profit tidak bisa memberikan pengaruh antara komisaris independen pada nilai perusahaan, karena komisaris yang dimiliki oleh perusahaan sampel kurang kompeten dalam menjalankan tugasnya sehingga tidak dapat meningkatkan profitabilitas. hal tersebut sesuai dengan teori agensi yang mengatakan banyaknya anggota komisaris independen yang kurang kompeten menyulitkan monitoring terhadap manajemen. Apabila profitabilitas tidak dapat meningkat maka sinyal yang diberikan perusahaan membuat investor kurang yakin dalam membeli saham pada perusahaan tersebut. Peningkatan harga saham dipengaruhi oleh seberapa banyak permintaan saham oleh investor, apabila permintaan saham perusahaan tidak mengalami peningkatan maka harga saham juga tidak meningkat. Tidak adanya peingkatan harga saham mencerminkan nilai perusahaan tidak mengalami peningkatan. Penelitian ini didukung oleh Ulfa (2017).

Profitabilitas tidak dapat memediasi komite audit pada nilai perusahaan, karena komite audit pada perusahan memiliki rangkap jabatan yang mempengaruhi kinerjanya menurun sehingga monitoring terhadap aktivitas manajemen menjadi kurang efektif. Kurang efektifnya monitoring terhadap manajemen membuat pertumbuhan profitabilitas kurang baik. Selaras dengan teori agensi yang mengatakan tugas komite audit membantu dewan komisaris. Apabila pertumbuhan profitabilitas tidak baik maka sinyal yang diberikan kepada pengguna laporan keuangan belum bisa membuat investor menanamkan saham di perusahaan, oleh karena itu nilai perusahaan belum mampu ditingkatkan. Hasil ini sejalan dengan penelitian Ulfa (2017).

Komite audit mempengaruhi nilai perusahaan meskipun sudah dimediasi oleh profitabilitas. Pihak institusional lebih memikirkan keuntungan jangka pendek dan akan menarik kembali dana yang diinvestasikannya apabila perusahaan tersebut kurang menguntungkan baginya. Hal ini sesuai dengan teori keagenan mengenai asumsi 
tentang sifat manusia yaitu pihak institusi hanya memikirkan kepentingannya sendiri. Dengan adanya hal tersebut perusahaan tidak dapat meningkatkan profitabilitas, sehingga informasi profitabilitas yang dikeluarkan oleh pihak manajemen tidak dapat memperkuat sinyal yang dapat mempengaruhi reaksi pasar dengan demikian tidak bisa menambah nilai perusaahaan. hasil penelitian ini di dukung oleh penelitian dari Afiani (2018).

Hasil uji sobel membuktikan $\mathrm{H} 5$ diterima artinya profitabilitas dapat menjadi mediasi hubungan green investment dengan nilai perusahaan. perusahaan yang menerapkan green investment akan memperoleh citra yang baik di lingkungan masyarakat sehingga investor tertarik terhadap perusahaan yang peduli terhadap lingkungan maupun sosial. Ketika perusahaan mampu menerapkan norma yang berlaku dimasyarakat sehubungan dengan aktivitas lingkungannya, maka perusahaan bisa diterima oleh masyarakat sehingga perusahaan akan tetap berjalan. Hal ini sesuai dengan teori legitimasi. Apabila perusahaan telah diterima oleh masyarakat maka kinerja dari perusahaan juga berjalan dengan baik sehingga pertumbuhan profitabilitas perusahaan menjadi sangat baik. Informasi mengenai lingkungan dan profitabilitas bisa digunakan menjadi keunggulan kompetitif dari perusahaan dan dapat dilihat melalui laporan keuangan. Perusahaan yang memberikan sinyal positif mengenai pertumbuhan profit yang baik akan mendapatkan respon positif dari investor dengan membeli saham perusahaan. Peningkatan permintaan saham berpengaruh pada peningkatan harga saham yang kemudian akan mencerminkan nilai perusahaan. Penelitian ini didukung oleh Fauziyyah (2019).

\section{PENUTUP}

Berdasarkan hasil penelitian dapat diketahui bahwa terdapat pengaruh corporate governance yang diwakili kepemilikan manajerial terhadap profitabilitas, hal ini berarti adanya saham yang dimiliki oleh pihak manajemen pada perusahaan dapat meningkatkan kinerja dari manajemen sehingga profitabilitas yang didapat oleh perusahaan juga tinggi. Terdapat pengaruh green investment terhadap profitabilitas, hal ini berarti semakin baik perusahaan menerapkan strategi green investment maka dukungan dari masyarakat terhadap kegiatan perusahaan semakin baik yang kemudian berpengaruh terhadap profitabilitas yang di dapat.

Terdapat pengaruh profitabilitas terhadap nilai perusahaan, yang berarti semakin tinggi profitabilitas akan membuat investor ingin memiliki saham perusahaan yang kemudian akan mempengaruhi nilai dari perusahaan. Profitabilitas mampu memediasi pengaruh green investment terhadap nilai perusahaan, hal ini berarti semakin tinggi profitabilitas mendorong green investment dalam peningkatan nilai perusahaan.

Berdasarkan penelitian, pengujian, dan pembahasan maka terdapat keterbatasan penelitian ini yaitu sampel penelitian menggunakan perusahaan indesk SRI KEHATI yang hanya memiliki peringkat PROPER, dimana perusahaan tidak cukup dalam mewakili sampel perusahaan. Saran dari penulis yaitu dapat meneliti topik yang sama tetapi menilai corporate governance dari segi yang berbeda, seperti indikator yang sudah dikembangkan oleh Indonesia Institute of Corporate Governance.

\section{REFERENCES:}

Agustina, M., \& Jogi, Y. 2015. Pengaruh Good Corporate Governance Terhadap Kinerja Perusahaan Pada Sektor Keuangan. Jurnal Business Accounting, Vol.3(No. 1), 223-232.

Andriana, A., \& Panggabean, R. R. 2017. The Effect Of Good Corporate Governance And Environmental Performance On Financial Performance Of The Proper Listed Company On Indonesia Stock Exchange. 
Binus Business Review, Vol. 8(1), 1-8. Https://Doi.Org/10.21512/Bbr.V8i1.1757.

Dowling, J., \& Pfeffer, J. 1975. Organizational Legitimacy: Social Values And Organizational Behavior. Pacific Sociological Journal Review, Vol. 18, 23-26.

Dwiridotjahjono, J. 2010. Penerapan Good Corporate Governance : Manfaat Dan Tantangan Serta Kesempatan Bagi Perusahaan Publik Di Indonesia. Jurnal Administrasi Bisnis, 5(2), 101-112.

Effendi, M. E. 2016. The Power Of Good Corporate Governance: Teori Dan Implikasi (Edisis 2). Jakarta Selatan: Salemba Empat.

Eyraud, L., \& Wane, A. 2011. Who 'S Going Green And Why ? Trends And Determinants Of Green Investment.

Fathonah, A. N. 2016. Pengaruh Penerapan Good Corporate Governance Financial Distress. Jurnal IImiah Akuntansi, Vo.. 1(No. 2), 133-150.

Indiani, N. P. L., \& Dewi, S. K. S. 2016. Pengaruh Variabel Tingkat Kesehatan Bank Terhadap Harga Saham Perbankan Di Bursa Efek Indonesia. Jurnal Manajemen, 5(5), 2756-2785.

Jensen, M. C., \& Meckling, W. H. 1976. Theory Of The Firm : Managerial Behavior Agency Costs And Ownership Strukture. Financial Economics, 3, 305-360.

Kementrian Lingkungan Hidup. 2013. Peraturan Lingkungan Hidup Ri.

Muchti, N. U. C. 2014. Pengaruh Kinerja Lingkungan Terhadap Reaksi Investor Melalui Pengungkapan Sustainability Report Nindha Utami Cahaya Muchti *). Jurnal Ekonomi, Vol. 9(No. 1), 81-95.

Murwaningsari, E. 2009. Hubungan Corporate Governance, Corporate Social Responsibilities Dan Corporate Financial Performance Dalam Satu Continuum. Jurnal Akuntansi Dan Keuangan, 11, No. 1, 30-41.

Oktaryani, S., A., I. N. N., \& Sofiyah, S. 2017. Pengaruh Good Corporate Governance Terhadap Nilai Perusahaan. Jurnal IImu Manajemen Dan Bisnis, 5(2), 45-58.

Prasetyo, A. B. 2014. Pengaruh Karakteristik Komite Audit Dan Perusahaan Terhadap Kecurangan Pelaporan Keuangan. Jurnal Akuntansi \& Auditing, 11(1), 1-24.

Putra, A. S., \& Nuzula, N. F. 2017. Pengaruh Corporate Governance Terhadap Profitabilitas ( Studi Pada Perusahaan Perbankan Yang Terdaftar Di Bursa Efek Indonesia Periode, 47(1), 103-112.

Rachman, H. H. 2018. Arah Dan Kebijakan Green Investment.

Rimardhani, H., Hidayat, R. R., \& Dwiatmanto. 2016. Pengaruh Mekanisme Good Corporate Governance Terhadap Profitabilitas Perusahaan ( Studi Pada Perusahaan Bumn Yang Terdaftar Di Bei Tahun 2012-2014). Jurnal Administrasi Bisnis, Vol.31(1), 167-175.

Rini, T. S., \& Ghozali, I. 2012. Pengaruh Pemegang Saham Institusi, Komisaris Independen Dan Komite Audit Terhadap Tingkat Profitabilitas Perusahaan. Journal Of Accounting, 1(1), 1-11.

Sanjaya, S., \& Rizky, M. F. 2016. Analisis Profitabilitas Dalam Menilai Kinerja Keuangan Pada Pt. Taspen (Persero) Medan. Kitabah, Vol: 2(No. 2).

Saputra, M., Nuraini, \& Rafiqa, I. 2017. The Influence Of Independent Commissioner , Audit Committee , And Institutional Ownership On Stock Price And Its Impact On Profitability ( Study At Lq45 Companies Listed On Indonesia. Account And Financial Management Journal, Vol. 2(12), 1199-1206. Https://Doi.Org/10.18535/Afmj/V2i12.05

Satriadi, F., Bagaskara, M. A., Pranoto, T., \& Haryono, L. 2016. Pengaruh Tata Kelola Perusahaan Terhadap Profitabilitas Pada Perusahaan Yang Terdaftar Di Bursa Efek Indonesia. Jurnal Akuntansii Dan Keuangan Indonesia, 186-209.

Spence, M. 1973. Job Market Signaling. The Quarterly Journal Of Economics, Vol. 87(No. 3), 355-374.

Sumarau, S. K. 2019. The Effect Of Investment Decisions, Funding Decisions, And Profitability On Manufacturing Company Value In Indonesia Stock Exchange 2015-2018 Period. Accountability Journal, Vol. 08(2), 85-90.

Syafitri, T., Nuzula, N. F., \& Nurlaily, F. 2018. Pengaruh Good Corporate Governance Terhadap Nilai Perusahaan ( Studi Pada Perusahaan Industri Sub Sektor Logam Dan Sejenisnya Yang Terdaftar Di Bei Periode 20122016 ). Jurnal Administrasi Bisnis (Jab), 56(1), 118-126.

Undang-Undang Republik Indonesia Nomor 40 Tahun 2007. (2007). Undang-Undang Republik Perseroan Terbatas.

Yatie, S. H., \& Tandika, D. 2019. Pengaruh Indeks Green Investment Terhadap Kinerja Keuangan Perusahaan Serta Dampaknya Pada Return Saham Perusahaan. Jurnal Manajemen, Vol. 5(No. 1), 107-114. 